\title{
DEMOGRAPHIC CHARACTERISTICS AND EMOTIONAL INTELLIGENCE AMONG ELEMENTARY SCHOOL TEACHERS IN MOSUL CITY
}

\author{
Zeyad Tariq Madallah', Dr.Kareem. R. Sachit ${ }^{2}$ *. \\ 1. Department of psychiatric mental health nursing, College of Nursing, University of Baghdad, City of \\ Baghdad, Iraq. \\ 2. Department of psychiatric mental health nursing, College of Nursing, University of Baghdad, City of \\ Baghdad, Iraq.
}

Corresponding author: Zeyad Tariq Madallah.

Email: zeyed.tareq1105@conursing.uobaghdad.edu.iq.

ORCID: 0000-0001-7390-8915.

\section{ABSTRACT}

Background: Educators should exhibit emotional intelligence in order to develop the necessary teaching skills. Individuals' emotional intelligence stages have been shown to be more significant than conventional cognitive abilities in dealing with a variety of issues (Supardi, S. 2014).

Objectives: This study aimed to assess the teachers' knowledge of emotional intelligence according to demographic characteristics.

Methods: A descriptive design was carried out from 27th February 2021 through 29th July 2021 to assess the teachers' knowledge towards emotional intelligence in Mosul city. A probability sampling (simple random technique) was used, consisted of 60 teachers, that consist (30) male, (30) female, were from primary schools of Nineveh Education Directorate. The researcher prepared a scale consisting of 40 multiple-choice questions to test teachers' knowledge of emotional intelligence. The questions include general information about emotional intelligence, self-awareness, selfmanagement, social awareness, and social management. To achieve the objectives of the study.

Results: the findings of this study indicates that the level of teachers' knowledge towards emotional intelligence and their demographic characteristics was low.

Recommendations: This study recommends a considerable shortage in the level of special education teachers' knowledge of emotional intelligence, which is one of the main requirements for special education teachers, especially as they deal with children with developmental disorders. Therefore, the authorities responsible for teachers must intensify the qualification and development courses to increase teachers' knowledge of emotional intelligence.

Keywords: Demographic Characteristics, elementary school teachers, Emotional Intelligence, Knowledge

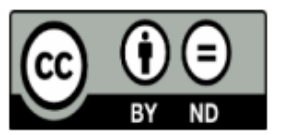

This work is licensed under a Creative Commons Attribution Non-Commercial 4.0 International License.

Received: 01 September 2021, Accepted: 17 December 2021, Available online: 20 January 2022 


\section{INTRODUCTION}

Emotional intelligence is defined as a person's ability to organize, persist on a course despite obstacles, control impulses, defer pleasure, regulate emotions, empathize, hope, and overcome barriers that prevent thinking (Goleman D. 1995). It can assess and express emotions, control emotions, and utilize emotions constructively to address problems in life as part of its adaptive abilities. Apart from accurately recognizing, evaluating, and expressing emotions and creating sentiments that promote emotional awareness, emotional intelligence entails the capacity to apply the knowledge acquired through these emotions successfully, the ability to regulate emotions for intellectual progress, and a pleasant mood (Druskat VU, et al. 2013). For the most part, it is about having a firm grip on other people's perspectives to bring value to the teacher's life via the information gained from them (Thompson HL.2009).

According to them, emotions are adaptive, organized responses involving physiological, cognitive, motivational, and experimental psychological systems. They act as internal events coordinating many psychological subsystems, such as physiological responses, cognition and consciousness, and awareness and awareness (Mayer JD, et al, 2007). It is critical to recognize that emotional intelligence includes two distinct aspects. This category includes personal abilities (such as self-awareness and self-management) and social abilities (social awareness and relationship management). The notion of personal awareness includes being consistently aware of one's emotions, self-evaluation, and confidence, among other things. Interpersonal and conflict management talents and the ability to work in a team are some other essential characteristics (Parthasarathy RR, 2009).

Education is a significant priority for the government in order to increase the country's economic competitiveness. As a result, governments spend a significant part of their resources to improving education's overall quality. Additionally, there are a sufficient number of classrooms and a reasonable teacher-to-student ratio (seven) (Khan, P., \& lqbal, M, 2012), as well as well-prepared textbooks and sufficient learning materials (eight), as well as technological infrastructures (Hmelo-Silver, Jeong, 2010 ; Jhurree, 2005). Classrooms that are densely packed are required, and teachers are among the essential players in the educational process. They will be unable to do their jobs effectively unless they get enough support and assistance. Employees' compensation is a key element in changing the quality of work and the reproductive capacity of people. Emotional intelligence has been proven to be beneficial for those who work in caring professions such as teaching. A teacher, including an $\mathrm{El}$, must be able to detect and understand emotions and effectively communicate them to be successful in their professions. The abilities of instructors are determined by their ability to detect and comprehend emotions (Chan, 2001; Nawaz and Anjali,2015; Nawaz and Anjali,2015; Nawaz, 2015). The teacher holds a vital role within the institutional structure, and he or she is responsible for a wide variety of tasks. It was necessary to have an uncompromising attitude toward their job and dedication to their profession or life if they wanted to pursue a career in the teaching sector. A happy workplace will be created for educators who are wellequipped and have access to El resources.

Employees' emotional intelligence influences their performance, and they are held responsible for the work they do as teachers. Employees with high emotional intelligence (EI) are more likely to productively handle their own and others' emotions. On the other hand, others who do not possess El to demonstrate a lack of skills are disinterested in their job and are entirely negative. This is suggested for instructors who have contradictory emotions and who are incompetent at their professions in general. Employees who possess emotional intelligence can maintain control of their moods and emotions in several different circumstances throughout their lives. Employees with emotional intelligence (El) can maintain control over their emotions and link a lower degree of psychological complexity with very high task performance and organizational commitment levels (Shanthini, Nawaz, 2020).

\section{METHOD}

A descriptive design was carried out from 27th February 2021 through 29th July 2021 to achieve the objectives of the present study. A nonprobability sample (selective) consisted of 60 teachers that consist (30) male (30) females were from primary schools of the Nineveh Education Directorate. The researcher prepared a scale composed of 40 multiple-choice questions to test teachers' knowledge of emotional abuse. The questions include general information about emotional intelligence, self-awareness, selfmanagement, social awareness, and social management. To achieve the objectives of the study. The reliability of these scales was evaluated by computing Cronbach Alpha Correlation coefficients using the split-half method. To ensure the validity of the rankings, method and procedure proposed to be carried out during the study, ten experts of different 
specialities related to the field of the present study were chosen. They were asked to review the scales format for clarity and adequacy to achieve the current study objective.

\section{RESULTS}

Table 1. Distribution of Demographic characteristics of the study subjects.

\begin{tabular}{|c|c|c|c|}
\hline Variables & & Freq. & $\%$ \\
\hline \multirow[t]{4}{*}{ Age } & $30-40$ & 29 & 48.3 \\
\hline & $41-50$ & 14 & 23.4 \\
\hline & $51-60$ & 17 & 28.3 \\
\hline & Total & 60 & 100 \\
\hline \multirow[t]{3}{*}{ Gender } & male & 30 & 50 \\
\hline & Female & 30 & 50 \\
\hline & Total & 60 & 100 \\
\hline \multirow[t]{4}{*}{ Educational level } & teacher house & 13 & 21.7 \\
\hline & Institute & 20 & 33.3 \\
\hline & College & 27 & 45 \\
\hline & Total & 60 & 100 \\
\hline \multirow[t]{7}{*}{ Years of experiences } & less than 5 & 7 & 11.7 \\
\hline & $6-10$ & 7 & 11.7 \\
\hline & $11-15$ & 18 & 30 \\
\hline & $16-20$ & 10 & 16.6 \\
\hline & $21-25$ & 9 & 15 \\
\hline & 25 and above & 9 & 15 \\
\hline & Total & 60 & 100 \\
\hline \multirow[t]{3}{*}{ Courses in developmental disorders } & yes & 42 & 70 \\
\hline & No & 18 & 30 \\
\hline & Total & 60 & 100 \\
\hline \multirow[t]{3}{*}{ Sources in emotional intelligence } & yes & 0 & 0 \\
\hline & No & 60 & 100 \\
\hline & Total & 60 & 100 \\
\hline \multirow[t]{3}{*}{ Courses in emotional intelligence } & yes & 0 & 0 \\
\hline & No & 60 & 100 \\
\hline & Total & 60 & 100 \\
\hline
\end{tabular}


Table 2. Distribution of study subjects (study and control groups) at baseline among the participants' knowledge about emotional intelligence (Total knowledge) according to their socio-demographical characteristics.

\begin{tabular}{|c|c|c|c|c|c|c|c|c|c|c|c|}
\hline \multirow{3}{*}{$\begin{array}{l}\text { Demographica } \\
\text { Characteristics }\end{array}$} & & \multicolumn{10}{|c|}{ Levels of Knowledge } \\
\hline & & \multicolumn{2}{|c|}{$\begin{array}{l}\text { Extreme } \\
\text { Low }\end{array}$} & \multicolumn{2}{|c|}{ Low } & \multicolumn{2}{|c|}{ Intermediate } & \multicolumn{2}{|c|}{ Good } & \multicolumn{2}{|c|}{ Total } \\
\hline & & $f$ & $\%$ & $\mathbf{F}$ & $\%$ & $f$ & $\%$ & $f$ & $\%$ & $f$ & $\%$ \\
\hline \multirow[t]{4}{*}{ Age (Years) } & $(30-39)$ & 0 & 0 & 19 & 31.6 & 10 & 16.6 & 0 & 0 & 29 & 48.3 \\
\hline & $(40-49)$ & 0 & 0 & 14 & 23.3 & 0 & 0 & 0 & 0 & 14 & 23.3 \\
\hline & $(50-60)$ & 0 & 0 & 14 & 23.3 & 3 & 5 & 0 & 0 & 17 & 28.4 \\
\hline & Total & 0 & 0 & 47 & 78.4 & 13 & 21.6 & 0 & 0 & 60 & 100 \\
\hline \multirow[t]{3}{*}{ Gender } & Male & 0 & 0 & 22 & 36.6 & 10 & 16.6 & 0 & 0 & 32 & 53.3 \\
\hline & Female & 0 & 0 & 25 & 41.7 & 3 & 5 & 0 & 0 & 28 & 46.7 \\
\hline & Total & 0 & 0 & 47 & 78.4 & 13 & 21.6 & 0 & 0 & 60 & 100 \\
\hline \multirow[t]{4}{*}{$\begin{array}{l}\text { Level of } \\
\text { Education }\end{array}$} & $\begin{array}{l}\text { Teachers } \\
\text { House }\end{array}$ & 0 & 0 & 11 & 18.3 & 2 & 3.3 & 0 & 0 & 13 & 21.6 \\
\hline & Institution & 0 & 0 & 17 & 28.4 & 3 & 5 & 0 & 0 & 20 & 33.4 \\
\hline & University & 0 & 0 & 19 & 31.6 & 8 & 13.3 & 0 & 0 & 27 & 45 \\
\hline & Total & 0 & 0 & 47 & 78.4 & 13 & 21.6 & 0 & 0 & 60 & 100 \\
\hline \multirow{7}{*}{$\begin{array}{l}\text { Years of } \\
\text { experiences }\end{array}$} & less than 5 & 0 & 0 & 5 & 8.3 & 3 & 5 & 0 & 0 & 8 & 13.3 \\
\hline & $6-10$ & 0 & 0 & 5 & 8.3 & 3 & 5 & 0 & 0 & 8 & 13.3 \\
\hline & $11-15$ & 0 & 0 & 15 & 25 & 1 & 1.6 & 0 & 0 & 16 & 26.8 \\
\hline & $16-20$ & 0 & 0 & 10 & 16.6 & 2 & 3.4 & 0 & 0 & 12 & 20 \\
\hline & $21-25$ & 0 & 0 & 8 & 13.3 & 2 & 3.4 & 0 & 0 & 10 & 16.6 \\
\hline & Above 25 & 0 & 0 & 4 & 6.9 & 2 & 3.4 & 0 & 0 & 6 & 10 \\
\hline & Total & 0 & 0 & 47 & 78.4 & 13 & 21.6 & 0 & 0 & 60 & 100 \\
\hline \multirow{3}{*}{$\begin{array}{l}\text { Courses in } \\
\text { development } \\
\text { al disorders }\end{array}$} & Yes & 0 & 0 & 34 & 56.8 & 8 & 13.3 & 0 & 0 & 42 & 70 \\
\hline & No & 0 & 0 & 13 & 21.6 & 5 & 8.3 & 0 & 0 & 18 & 30 \\
\hline & Total & 0 & 0 & 47 & 78.4 & 13 & 21.6 & 0 & 0 & 60 & 100 \\
\hline \multirow{3}{*}{$\begin{array}{l}\text { Courses in } \\
\text { emotional } \\
\text { intelligence }\end{array}$} & Yes & 0 & 0 & 27 & 45 & 5 & 8.3 & 0 & 0 & 32 & 53.3 \\
\hline & No & 0 & 0 & 20 & 33.4 & 8 & 13.3 & 0 & 0 & 28 & 46.7 \\
\hline & Total & 0 & 0 & 47 & 78.4 & 13 & 21.6 & 0 & 0 & 60 & 100 \\
\hline & $\begin{array}{l}\text { Frequency } \\
0-29) \text {, Goo }\end{array}$ & & & & tra & & ow & & & & \\
\hline
\end{tabular}

\section{DISCUSSION}

According to Table (1.2), participants (78.4\%) had a low level of expertise. According to the study, $31.6 \%$ of those aged 30 to 39 lacked basic knowledge. This Table demonstrates that, based on the gender of the participants, the majority of female teachers (45\%) had a low level of knowledge of emotional intelligence. In terms of education, the figure indicates that a third of teachers with a teacher's college degree (31.6\%) are acquainted with emotional intelligence. In terms of years of experience, the Table reveals that $(25 \%)$ of teachers have a poor degree of skill in the age range (11-15). Finally, according to developmental disorders courses, more than (56.8 $\%)$ of teachers have a low level of knowledge about emotional intelligence.

Male and female leaders exhibit substantial variations in emotional competence, with male leaders outperforming female leaders in the sub- themes of social awareness, self-management, and relationship management, as well as selfawareness. Male and female leaders show substantial disparities in emotional competence, according to Don (2009).

According to Sala (2002), old age allows one to gain more knowledge and emotional maturity. Emotional competency develops due to one's learning and experiences (Boyatzis \& Sala, 2004). As Goleman (1998) points out, one is emotional intelligence increases as one grows older $(16,17$, 18).

Also, Supardi(2014) and S. Supardi are two similar names (2014)to this study. According to age groups, there is a significant difference in emotional intelligence among teachers. For example, there is a significant difference between teachers aged 25 to 30 and those aged 35 to 40 . There is also a significant difference between teachers aged 45 to five years or more and those aged 45 to five years or more. Nonetheless, there is no statistically significant difference in emotional intelligence among 
instructors 25 years or older, 35 years or older, 55 years or older, and the other age groups studied. In addition, S. Supardi is disagreement (2014). There is no difference in teacher emotional intelligence between teachers with S1 and S2 degrees in the subthemes of self-awareness, selfmanagement, and social awareness. Nonetheless, there is a distinction between the subtheme of relationship management and the overall theme of relationship management. Although there is a difference between the subtheme of relationship management and the broader theme, this divergence is not significant.

Following the results of Edannur, S. (2010), the participants in the study had an average level of Emotional Intelligence. In terms of Emotional Intelligence, there were no differences between the teacher educators based on their gender or region.

Age has a significant effect on emotional intelligence, and a person's emotional intelligence may be developed via a variety of life events and experiences, especially those that have a considerable impact on a person's emotional intelligence.

Due to their work with students of varying intelligence levels and other problems that necessitate them understanding the different conditions of the students and selecting the best methods to deal with them to solve these problems and deliver scientific material to all students, teachers must continually improve their emotional skills.

\section{CONCLUSIONS}

This study concludes a considerable lack of knowledge regarding emotional intelligence (EI) among elementary school teachers.

\section{ETHICAL CONSIDERATIONS COMPLIANCE WITH ETHICAL GUIDELINES}

The questionnaire was approved based on the official permission granted by the Nineveh Governorate Education Directorate to ensure their approval and to facilitate the researcher's task by entering special education schools and applying the questionnaire to teachers after clarifying the purpose of the study to them and obtaining their approval.

\section{FUNDING}

This research did not receive any grant from funding agencies in the public, commercial, or non-profit sectors.

\section{AUTHOR'S CONTRIBUTIONS}

Study concept: Dr. Kareem. R. Sachit; Writing the original draft: Zeyad Tariq; Data collection: Data analysis: Zeyad Tariq, Reviewing the final edition: All authors.
DISCLOSURE STATEMENT: The authors reported no conflict of interest. Thanks and appreciation to the Directorate of Education of Nineveh Governorate for providing the opportunity for researchers to complete the research, as well as for the special education teachers who answered the research questionnaire.

\section{ACKNOWLEDGEMENTS}

We thank the anonymous referees for their useful suggestions.

\section{REFERENCES}

Boyatzis, R. E., \& Sala, F. (2004). Assessing emotional intelligence competencies. In G. Geher (Ed.), The measurement of emotional intelligence (pp. 147-186). Hauppauge, NY: Nova Science Publishers.

Chan, Caputi and Roberts Ciarrochi, (2001). "Elin everyday life: a scientific inquiry," Phidalephia, Psychology Press, pp. 98-132.

Don, Y. (2009). Korelasi dan pengaruh kompetensi emosi terhadap kepemimpinan sekolah: Perbandingan antara sekolah berkesan dan sekolah kurang berkesan. Thesis: Fakulti Pendidikan Universiti Malaya Kuala Lumpur. Tidak diterbitkan.

Druskat VU, Mount G, Sala F. (2013) Linking emotional intelligence and performance at work: Current research evidence with individuals and groups: New Jersey: Psychology Press,.

Edannur, S. (2010). Emotional intelligence of teacher educators. International Journal of Educational Sciences, 2(2), 115-121.

Goleman D. (1995)Emotional intelligence. New York: Bantam,131-47.

Goleman, D. (1998). Working with emotional intelligence. New York: Bantan.

H., \& Hmelo-Silver, C. E Jeong, (2010)."Productive use of learning resources in an online problembased learning environment," Computers in Human Behavior, vol. 26, no. 1, pp. 84-99.

Khan, P., \& Iqbal, M, (2012). "Overcrowded classroom: A serious problem for teachers," University of Science and Information Technology, vol. 49, pp. 10162-10165.

Mayer JD, Salovey P, Mayer-Salovey-Caruso (2007).Emotional Intelligence Test (MSCEIT). Toronto, Canada: Multi-Health Systems Inc.

N. Nawaz, (2015). "An empirical study on employee competence in relation to Elin Bahrain," Int. J. Econ. Commer. Manag. United Kingdom, vol. 3, no. 5, pp. 1555-1568,

N. Nawaz and M. G. Anjali, (2015). "An empirical study on personal competence in relation to Elin 
Bahrain," Manag. Organ. Stud., vol. 2, no. 3, pp. 1-16, Jun.

N. Nawaz and M. G. Anjali, (2015). "An empirical study on social competence in relation to emotional intelligence in Bahrain," J. Contemporary Manag., vol. 4, no. 4, pp. 57-68.

Parthasarathy RR. (2009) Emotional intelligence and the quality manager: Beauty and the beast? JQP;31:26-48.

Sala, F. (2003). Leadership in education: Effective UK college principal. Nonprofit Management Leadership, 14(2), 171-189. http://dx.doi.org/10.1002/nml.28.

Shanthini, V. K., \& Nawaz, N.(2020) Assessment Of Emotional Intelligence Among The Primary Schools Teachers: A Comparative Study. international journal of scientific \& technology research volume 9 , issue 03 .

Supardi,S. (2014). Teacher Emotional Intelligences: A Demographic Perspective of a Comparational Study of the Teachers at Public Senior High Schools at Tangerang, International Education Studies, 7(10), 112-121.

Thompson HL.(2009) Emotional intelligence, stress, and catastrophic leadership failure. In: Hughes M, Thompson HL, James Bradford Terrell $J B$, eds. Handbook for Developing Emotional and Social Intelligence:Best Practices, Case Studies, and Strategies. USA: Pfeiffer Inc.,111-38.

V Jhurree, (2005). "Technology integration in education in developing countries: Guidelines to policy makers," International Education Journal, vol. 6,no. 4, pp. 467-483. 